\title{
Analisis Kesalahan Siswa Dalam Menyelesaikan Soal Cerita Pada Materi Sistem Persamaan Linear Tiga Variabel
}

\author{
Sri Mulyani ${ }^{1}$, Haerudin ${ }^{2}$ \\ 1,2Program Studi Pendidikan Matematika Universitas Singaperbangsa Karawang \\ Email:1710631050012@student.unsika.ac.id
}

\begin{abstract}
The purpose of this study was to describe students' mistakes in solving story problems on the material of the three-variable linear equation system (SPLTV) based on the Newman procedure to minimize the occurrence of the same errors in the future. The approach used is a qualitative approach with descriptive methods. The subjects in this study were 25 students of class X SMAN 14 Bekasi. The test instruments used was 2 items in the description. In this study using errors according to Newman to analyze student errors. From the results of the analysis, it was found that the average error rate of students in answering SPLTV story questions was $34.4 \%$ and the remaining $65.6 \%$ of students could answer correctly and correctly. Of the two questions given, question number 1 had more percentage of students who made mistakes. There are various kinds of mistakes made by students, based on the error analysis according to Newman, there was a reading error of $0 \%$ because none of the students read the questions wrongly, the error in understanding was $30.23 \%$ because the students did not write known and asked, the transformation error was equal to $20.93 \%$ because the students were not able to transform the questions given into a mathematical form so they could not make mathematical models, $24.42 \%$ error in processing skills was due to the lack of students' accuracy in calculating which resulted in errors, and errors in writing the final answer of $24,42 \%$ because the students were incomplete in making conclusions.
\end{abstract}

Keywords: student errors, Newman procedure, three-variable linear equation system, story problems

\begin{abstract}
Abstrak : Tujuan penelitian ini untuk mendeskripsikan kesalahan siswa dalam menyelesaikan soal cerita pada materi sistem persamaan linear tiga variabel (SPLTV) berdasarkan prosedur Newman untuk meminimalisir terjadinya kesalahan-kesalahan yang sama dikemudian hari. Pendekatan yang digunakan adalah pendekatan kualitatif dengan metode deskriptif. Subjek pada penelitian ini adalah siswa kelas X SMAN 14 Bekasi sebanyak 25 siswa. Instrumen tes yang digunakan sebanyak 2 butir soal uraian. Pada penelitian ini menggunakan kesalahan menurut Newman untuk menganalisis kesalahan siswa. Dari hasil analisis diperoleh rata-rata tingkat kesalahan siswa dalam menjawab soal cerita SPLTV sebanyak 34,4\% dan sisanya 65,6\% siswa dapat menjawab dengan baik dan benar. Dari dua soal yang diberikan, soal nomor 1 lebih banyak persentase siswa yang melakukan kesalahan. Ada bermacam-macam kesalahan yang dilakukan siswa, berdasarkan analisis kesalahan menurut Newman diperoleh kesalahan membaca sebesar 0\% karena tidak terdapat satupun siswa yang salah dalam membaca soal, kesalahan memahami sebesar 30,23\% ini disebabkan siswa tidak menulis diketahui dan ditanya, kesalahan transformasi sebesar 20,93\% disebabkan siswa belum mampu menstransformasikan soal yang diberikan menjadi bentuk matematis sehingga tidak bisa membuat model matematika, kesalahan keterampilan proses sebesar $24,42 \%$ disebabkan kurangnya ketelitian siswa dalam melakukan perhitungan yang mengakibatkan terjadinya kesalahan, dan kesalahan penulisan jawaban akhir sebesar 24,42\% disebabkan siswa kurang lengkap dalam membuat kesimpulan.
\end{abstract}

Kata kunci: Kesalahan Siswa, Prosedur Newman, Sistem Persamaan Linear Tiga Variabel, Soal Cerita 


\section{PENDAHULUAN}

Matematika memiliki peranan penting dalam pendidikan. Sejak TK sampai Kuliah kita belajar matematika. Pada kehidupan sehari-hari matematika digunakan untuk menghitung laba rugi, gaji karyawan, perkiraan bayar pajak dll. Saat belajar matematika kita dibiasakan untuk bernalar, berpikir analitis dan kreatif karena ketika kita ingin menyelesaikan permasalahan matematika maka kita akan berpikir cara yang tepat supaya kita bisa menyelesaikan permasalahan tersebut. Aspek yang harus dikuasai oleh siswa ialah kemampuan pemecahan masalah. Untuk mengetahui kemampuan pemecahan masalah matematika siswa biasa digunakan soal cerita (Sholihah, 2018).

Permasalahan kontekstual matematika berbentuk narasi disebut soal cerita. Menurut Nugroho \& Sutarni (Agustini \& Pujiastuti, 2020) dibutuhkan pemahaman mendalam untuk memahami soal cerita dan penyelesaiannya tidak mudah karena memperhatikan prosesnya bukan hanya jawaban akhir saja. Namun, kesulitan menyelesaikan soal cerita masih banyak dialami siswa. Hal tersebut dapat diketahui melalui beberapa hasil penelitian, diantaranya adalah hasil penelitian (Halim \& Rasidah, 2019) diperoleh jenis kesalahan-kesalahan siswa meliputi kesalahan ketika memahami soal, melakukan transformasi dan penulisan jawaban akhir. Sedangkan berdasarkan hasil penelitian (Rusmania, 2015) diperoleh kesalahan ketika membuat ungkapan matematika, tidak bisa memutuskan rumus yang akan digunakan, salah konsep, perhitungan dan menafsirkan solusi. Berdasarkan hal tersebut telihat banyak siswa yang membuat kesalahan dalam pemecahan masalah matematis.

Sistem persamaan linear tiga variabel (SPLTV) merupakan materi matematika kelas X SMA. Implementasi konsep materi SPLTV dapat ditemukan diberbagai bidang kehidupan, contohnya di bidang ekonomi konsep SPLTV digunakan untuk menentukan harga pembelian suatu barang dan mencari keuntungan penjualan, dalam bidang keuangan dan dunia usaha konsep SPLTV digunakan untuk menganekaragamkan investasi dan perhitungan pinjaman, dan masih banyak kegunaan SPLTV dalam bidang lain. Materi SPLTV dipandang sebagai materi yang cukup sulit karena biasanya penyajian soal dalam materi SPLTV berbentuk soal cerita mengenai masalah kontekstual. Berdasarkan hasil observasi di SMAN 14 Bekasi menunjukkan bahwa siswa mengalami kesulitan jika soal bervariasi atau berbeda walaupun pada konsep yang sama. Hasil ulangan harian (UH) 36 siswa kelas X SMAN 14 Bekasi pada materi SPLTV diperoleh nilai rata-rata 58,89. Nilai KKM matematika di SMAN 14 Bekasi yaitu 70, maka terlihat nilai rata-rata UH pada materi SPLTV masih dibawah KKM. Maka dapat disimpulkan SMAN 14 Bekasi masih mengalami kesulitan saat menyelesaikan permasalahan SPLTV khususnya pada soal cerita.

Beberapa peneliti menerapkan metode Newman untuk menganalisis kesalahan yang dilakukan siswa saat menyelesaikan soal cerita, diantaranya (Islamiyah, Prayitno, \& Amrullah, 2018), (Rahmawati \& Permata, 2018), (Wardhani \& Firmansyah, 2019), dan (Halim \& Rasidah, 2019). Menurut Newman (Wardhani \& Firmansyah, 2019) tahapan yang harus dilakukan siswa untuk menyelesaikan masalah matematika, yaitu 
membaca (reading), memahami (comprehension), transformasi (transformation), keterampilan proses (process skill) dan penulisan jawaban akhir (encoding). Adapun tujuan dari penelitian ini yaitu untuk mendeskripsikan kesalahan siswa dalam menyelesaikan soal cerita pada materi SPLTV menurut prosedur Newman untuk meminimalisir terjadinya kesalahan-kesalahan yang sama di kemudian hari.

\section{METODE}

Pendekatan yang digunakan adalah pendekatan kualitatif dengan metode deskriptif yang bertujuan untuk mendeskripsikan kesalahan siswa kelas $\mathrm{X}$ saat menyelesaikan soal cerita pada materi SPLTV. Menurut Sukmadinata (Kurniawan, Juliangkary, \& Pratama, 2019) penelitian deskriptif kualitatif difokuskan untuk menginterpretasikan kejadian yang bersifat alami atau buatan manusia dengan memperhatikan kualitas, keistimewaan, hubungan antar kegiatan. Penelitian deskriptif menjelaskan suatu kondisi yang apa adanya tanpa melakukan manipulasi (Hamsiah, Masjudin, \& Kurniawan, 2017). Subjek penelitian ini adalah siswa kelas X SMAN 14 Bekasi sebanyak 25 siswa. Instrumen tes yang dipakai sebanyak 2 butir soal uraian yang diadopsi dari (Aulia, 2020).

\section{HASIL DAN PEMBAHASAN}

Diberikan tes kemampuan sebanyak 2 soal cerita materi SPLTV kepada 25 siswa kelas X SMAN 14 Bekasi. Hasil tes siswa digolongkan berdasarkan tiga kategori yaitu tinggi, sedang dan rendah. Adapun pengkategorian menggunakan cara yang dijelaskan oleh (Azwar, 2014:149).

Tabel 1. Hasil Tes Siswa Berdasarkan Kategori

\begin{tabular}{cccc}
\hline Interval & Kategori & Jumlah Siswa & Persentase \\
\hline$X \geq 86,59$ & Tinggi & 4 & $16 \%$ \\
$42,21 \leq X<86,59$ & Sedang & 17 & $68 \%$ \\
$X<42,21$ & Rendah & 4 & $16 \%$ \\
\hline
\end{tabular}

Berdasarkan pada Tabel 1 jika nilai siswa lebih dari atau sama dengan 86,59 maka berada pada kategori tinggi, jika nilai siswa lebih dari atau sama dengan 42,21 dan kurang dari 86,59 maka berada pada kategori sedang, dan jika nilai siswa kurang dari 42,21 maka berada pada kategori rendah. Nilai 86,59 diperoleh dari hasil nilai rata-rata 25 siswa ditambah satu dikali standar deviasi 25 siswa, sedangkan nilai 42,21 diperoleh dari hasil nilai rata-rata 25 siswa dikurang satu dikali standar deviasi 25 siswa. Merujuk pada tabel di atas dari 25 siswa, ada 4 siswa atau 16\% siswa kategori tinggi, 17 siswa atau $68 \%$ siswa kategori sedang, dan 4 siswa atau 16\% siswa kategori rendah. Pada siswa kategori kemampuan tinggi diperoleh tidak terdapat satupun siswa yang salah dalam membaca soal, melakukan transformasi dan keterampilan proses, 1 siswa melakukan kesalahan memahami pada soal ke-2, dan 2 siswa melakukan kesalahan penulisan jawaban akhir pada soal ke-2. Sedangkan siswa dengan kategori kemampuan sedang diperoleh tidak terdapat satupun siswa yang salah membaca soal, 7 siswa melakukan kesalahan memahami pada soal ke-1 dan 12 siswa soal ke-2, 10 siswa melakukan kesalahan transformasi pada soal ke-1 dan 1 siswa soal ke-2, 10 siswa 
melakukan kesalahan keterampilan proses pada soal ke-1 dan 3 siswa soal ke-2, 8 siswa melakukan kesalahan penulisan jawaban akhir pada soal ke-1 dan 4 siswa soal ke-2. Siswa dengan kategori kemampuan rendah diperoleh tidak terdapat satupun siswa yang salah membaca soal, 2 siswa melakukan kesalahan memahami pada soal ke-1 dan 4 siswa soal ke-2, 4 siswa melakukan kesalahan transformasi pada soal ke-1 dan 3 siswa soal ke-2, 4 siswa melakukan kesalahan keterampilan proses pada soal ke-1 dan soal ke2, 4 siswa melakukan kesalahan penulisan jawaban akhir pada soal ke-1 dan 3 siswa soal ke-2. Untuk mengetahui persentase dari setiap jenis kesalahan disajikan pada Tabel 2.

Tabel 2. Persentase Setiap Jenis Kesalahan

\begin{tabular}{cccccc}
\hline Soal & $\begin{array}{c}\text { Kesalahan } \\
\text { Membaca }\end{array}$ & $\begin{array}{c}\text { Kesalahan } \\
\text { Pemahaman }\end{array}$ & $\begin{array}{c}\text { Kesalahan } \\
\text { Transformasi }\end{array}$ & $\begin{array}{c}\text { Kesalahan } \\
\text { Keterampilan } \\
\text { Proses }\end{array}$ & $\begin{array}{c}\text { Kesalahan } \\
\text { Penulisan } \\
\text { Jawaban Akhir }\end{array}$ \\
\hline 1 & 0 & 9 & 14 & 14 & 12 \\
2 & 0 & 17 & 4 & 7 & 9 \\
Jumlah & 0 & 26 & 18 & 21 & 21 \\
Persentase & $0 \%$ & $30,23 \%$ & $20,93 \%$ & $24,42 \%$ & $24,42 \%$ \\
\hline
\end{tabular}

Berdasarkan Tabel 2, tampak bahwa jenis kesalahan terbesar adalah kesalahan pemahaman sebesar 30,23\%. Sedangkan kesalahan terkecil adalah kesalahan membaca sebesar $0 \%$. Pada kesalahan membaca tidak terdapat satupun siswa yang salah ketika membaca soal karena semua siswa membaca soal dengan baik. Siswa melakukan kesalahan pada tahapan pemahaman untuk soal nomor 1 dan 2 masing-masing sebanyak 9 dan 17 siswa, siswa melakukan kesalahan karena siswa tidak menulis diketahui dan ditanya, tidak lengkap saat menulis diketahui, hanya menulis diketahui sedangkan yang ditanyakan tidak ditulis, dan tidak bisa mencerna soal dengan baik sehingga tidak tepat ketika menulis diketahui dan ditanya. Kesalahan saat melakukan transformasi untuk soal nomor 1 dan 2 masing-masing sebanyak 14 dan 4 siswa, kesalahan siswa yaitu siswa tidak dapat menstransformasikan soal menjadi bentuk matematis sehingga tidak bisa membuat pemodelan matematika, siswa kesulitan untuk membuat model matematika sehingga terdapat beberapa siswa melakukan perhitungan dengan cara coba-coba tanpa membuat model matematikanya terlebih dahulu. Kesalahan pada tahapan keterampilan proses untuk soal nomor 1 dan 2 masing-masing sebanyak 14 dan 7 siswa, kesalahan siswa yaitu kurang teliti dalam perhitungannya, kekeliruan saat melakukan eliminasi maupun substitusi. Kesalahan saat penulisan jawaban akhir untuk soal nomor 1 dan 2 masing-masing sebanyak 12 dan 9 siswa, kesalahan siswa yaitu siswa tidak membuat sebuah kesimpulan setelah selesai melakukan perhitungan. 
Berikut adalah contoh-contoh kesalahan siswa.

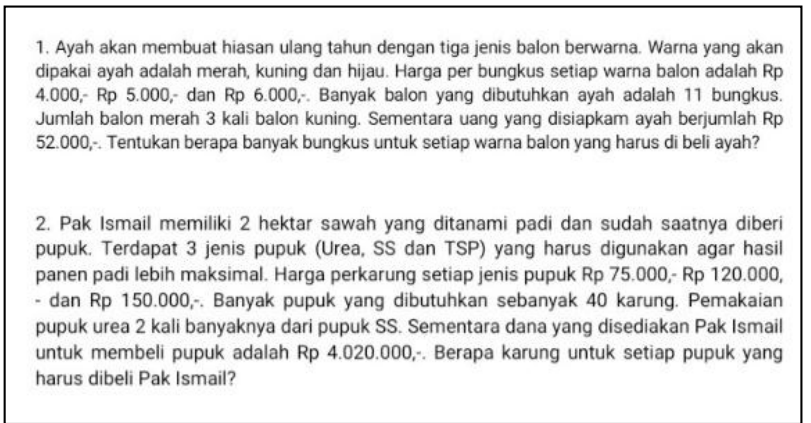

Gambar 1. Soal nomor 1 dan 2

\section{a. Kesalahan Membaca}

Pada tahap membaca tidak terdapat satupun siswa yang salah dalam membaca soal karena semua siswa membaca soal dengan baik.

\section{b. Kesalahan Pemahaman}

Pada tahap pemahaman kesalahan terbanyak terdapat pada soal ke- 2 sebanyak 17 siswa. Bersumber pada jawaban siswa dari 17 siswa yang melakukan kesalahan terdapat 1 siswa kemampuan tinggi, 12 siswa kemampuan sedang dan 4 siswa kemampuan rendah. Dari 17 siswa yang melakukan kesalahan, 4 siswa tidak menulis diketahui dan ditanya, 3 siswa menulis diketahui namun tidak menulis apa yang ditanya, 8 siswa tidak menulis diketahui dan ditanya hanya membuat pemisalan yaitu dengan memisalkan pupuk Urea dengan variabel $\mathrm{x}$, pupuk SS dengan variabel y dan pupuk TSP dengan variabel z, 2 siswa menulis diketahui namun tidak lengkap dan tidak menulis apa yang ditanya. Berikut adalah contoh kesalahan pemahaman.

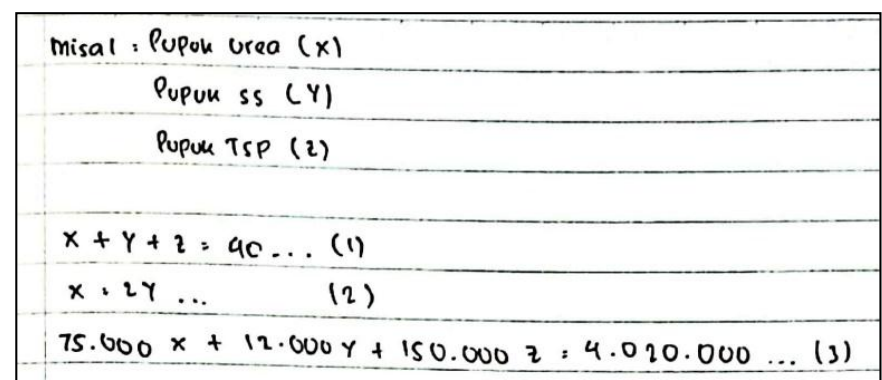

Gambar 2. Contoh Kesalahan Pemahaman Pada Soal 2

Berdasarkan Gambar 2 terlihat siswa S-12 melakukan kesalahan pemahaman. Siswa tidak menulis diketahui dan ditanya. Siswa hanya membuat pemisalan pupuk urea dengan variabel $\mathrm{x}$, pupuk SS dengan variabel y dan pupuk TSP dengan variabel $\mathrm{z}$, kemudian siswa langsung membuat pemodelan matematika. Merujuk hasil penelitian (Rahmawati \& Permata, 2018) siswa melakukan kesalahan pemahaman karena tidak menulis diketahui dan ditanya. 


\section{c. Kesalahan Transformasi}

Kesalahan terbanyak saat melakukan transformasi terdapat pada soal ke-1 sebanyak 14 siswa. Bersumber pada jawaban siswa dari 14 siswa yang melakukan kesalahan terdapat 10 siswa kemampuan sedang dan 4 siswa kemampuan rendah. Dari 14 siswa yang melakukan kesalahan, 3 siswa tidak membuat model matematika tetapi melakukan perbandingan yaitu dengan membandingkan jumlah balon merah, kuning dan hijau, hal ini tidak sesuai dengan konsep SPLTV, seharusnya siswa membuat model matematika terlebih dahulu kemudian baru diselesaikan dengan menggunakan cara eliminasi, substitusi, campuran maupun determinan,, 5 siswa tidak membuat model matematika tetapi menggunakan cara coba-coba untuk menyelesaikan permasalahan, 2 siswa menggunakan cara atau rumus yang salah, 4 siswa tidak melakukan transformasi sama sekali. Berikut adalah contoh kesalahan transformasi.

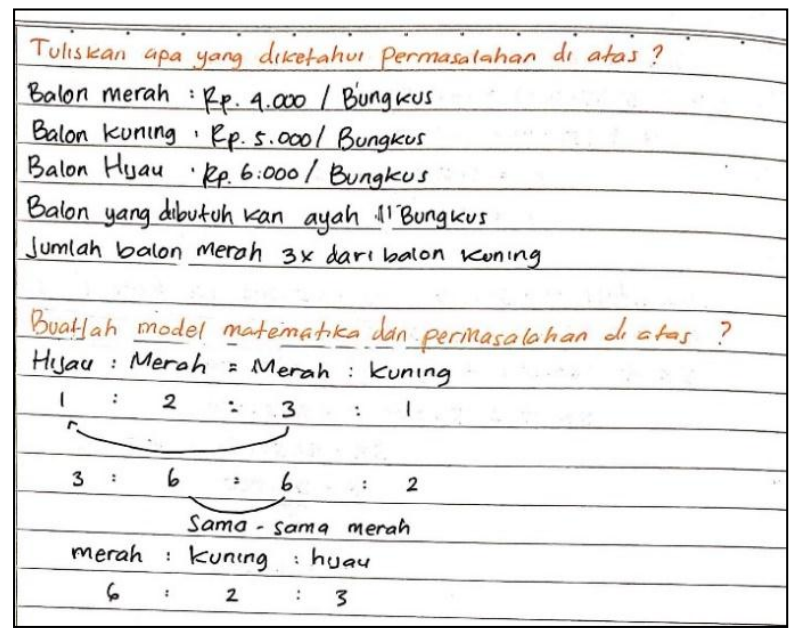

Gambar 3. Contoh Kesalahan Transformasi Pada Soal 1

Gambar 3 di atas terlihat siswa S-6 melakukan kesalahan transformasi. Siswa belum mampu menstransformasikan soal yang diberikan menjadi bentuk matematis sehingga tidak bisa membuat pemodelan matematika, terlihat dari jawaban siswa yang mengerjakan soal menggunakan perbandingan, ini tidak sesuai dengan konsep SPLTV, seharusnya siswa membuat pemodelan matematika, kemudian baru mencari solusinya. Merujuk hasil penelitian (Islamiyah et al., 2018) siswa melakukan kesalahan transformasi karena tidak adanya sebuah rencana atau strategi atau pemodelan matematika.

\section{d. Kesalahan Keterampilan Proses}

Kesalahan terbanyak pada tahapan keterampilan proses terdapat pada soal ke-1 sebanyak 14 siswa. Bersumber pada jawaban siswa dari 14 siswa yang melakukan kesalahan terdapat 10 siswa kemampuan sedang dan 4 siswa kemampuan rendah. Dari 14 siswa yang melakukan kesalahan, 5 siswa kurang teliti atau kurang cermat dalam perhitungannya yang mengakibatkan terjadinya kesalahan operasi perkalian dan pengurangan pada saat eliminasi, 2 siswa tidak melakukan proses penyelesaian karena 
salah menentukan rumus, 1 siswa tidak melakukan perhitungan, 6 siswa tidak membuat pemodelan sehingga saat mengerjakan untuk melakukan penyelesaian hanya berdasarkan logika atau coba-coba. Berikut adalah contoh kesalahan keterampilan proses.

$$
\begin{array}{|l|l|l|}
\hline 4 x+5 y+6 z=52 & 1 & 4 x+5 y+6 z=52 \\
\hline x+y+z=11 & 6 & 6 x+6 y+6 z=62 \\
\hline
\end{array}
$$

Gambar 4. Contoh Kesalahan Keterampilan Proses Pada Soal 1

Berdasarkan Gambar 4 terlihat siswa S-5 melakukan kesalahan keterampilan proses karena kurang teliti dalam perhitungannya. Seharusnya persamaan $\mathrm{x}+\mathrm{y}+\mathrm{z}=$ 11 dikali 6 hasilnya $6 x+6 y+6 z=66$, tetapi siswa menulis $6 x+6 y+6 z=62$. Merujuk pada hasil penelitian (Rahmawati \& Permata, 2018) siswa melakukan kesalahan keterampilan proses karena kesalahan komputasi atau kesalahan perhitungan.

\section{e. Kesalahan Penulisan Jawaban Akhir}

Kesalahan terbanyak saat penulisan jawaban akhir terdapat pada soal ke-1 sebanyak 12 siswa. Bersumber pada jawaban siswa dari 12 siswa yang melakukan kesalahan terdapat 8 siswa kemampuan sedang dan 4 siswa kemampuan rendah. Dari 12 siswa yang melakukan kesalahan, 3 siswa tidak menulis kesimpulan hanya menulis merah $=6$ bungkus, kuning $=2$ bungkus, hijau $=3$ bungkus, 3 siswa tidak menulis kesimpulan atau jawaban akhir hanya menulis $\mathrm{x}=6, \mathrm{y}=2, \mathrm{z}=3$, siswa tidak mencocokkan nilai setiap variabel dengan nilai yang diwakilinya. dan 6 siswa tidak menulis kesimpulan. Berikut adalah contoh kesalahan siswa.

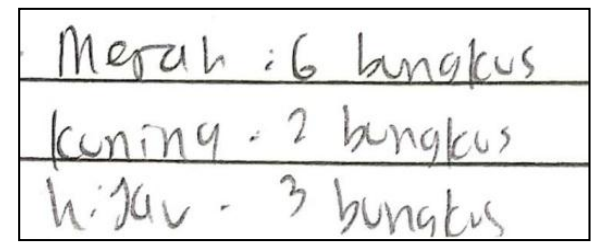

Gambar 5. Contoh Kesalahan Penulisan Jawaban Akhir Pada Soal 1

Berdasarkan Gambar 5 terlihat siswa S-2 melakukan kesalahan penulisan jawaban akhir karena tidak membuat kesimpulan, siswa hanya menulis merah $=6$ bungkus, kuning $=2$ bungkus dan hijau $=3$ bungkus. Seharusnya siswa membuat kesimpulan dengan menuliskan " Jadi, banyaknya balon yang harus dibeli ayah untuk setiap warna yaitu balon merah 6 bungkus, balon kuning 2 bungkus dan balon hijau 3 bungkus." Merujuk pada hasil penelitian (Islamiyah et al., 2018) kesalahan penulisan jawaban dikarenakan tidak membuat sebuah kesimpulan, tidak tepat dalam membuat kesimpulan dan kurang lengkap dalam membuat kesimpulan.

Untuk mengetahui nilai 25 siswa pada soal nomor 1 dan 2 dapat dilihat pada tabel berikut.

Tabel 3. Nilai 25 Siswa Pada Soal Nomor 1 dan 2 


\begin{tabular}{|c|c|c|c|}
\hline Siswa & Soal 1 & Soal 2 & Nilai \\
\hline S-1 & 3 & 5 & 8 \\
\hline S-2 & 3 & 2 & 5 \\
\hline S-3 & 5 & 4 & 9 \\
\hline S-4 & 3 & 4 & 7 \\
\hline S-5 & 4 & 4 & 8 \\
\hline S-6 & 3 & 5 & 8 \\
\hline S-7 & 1 & 1 & 2 \\
\hline S-8 & 2 & 5 & 7 \\
\hline S-9 & 1 & 3 & 4 \\
\hline S-10 & 3 & 5 & 8 \\
\hline S-11 & 5 & 1 & 6 \\
\hline S-12 & 3 & 3 & 6 \\
\hline$S-13$ & 5 & 4 & 9 \\
\hline S-14 & 3 & 4 & 7 \\
\hline S-15 & 2 & 1 & 3 \\
\hline S-16 & 3 & 3 & 6 \\
\hline S-17 & 3 & 4 & 7 \\
\hline S-18 & 3 & 4 & 7 \\
\hline$S-19$ & 2 & 1 & 3 \\
\hline$S-20$ & 3 & 3 & 6 \\
\hline$S-21$ & 3 & 4 & 7 \\
\hline$S-22$ & 5 & 4 & 9 \\
\hline$S-23$ & 2 & 5 & 7 \\
\hline S-24 & 1 & 4 & 5 \\
\hline S-25 & 5 & 5 & 10 \\
\hline Jumlah & 76 & 88 & 164 \\
\hline Rata-rata & 3,04 & 3,52 & 6,56 \\
\hline Persentase kesalahan & $39,2 \%$ & $29,6 \%$ & \\
\hline $\begin{array}{l}\text { Rata-rata persentase } \\
\text { kesalahan }\end{array}$ & \multicolumn{2}{|c|}{$34,4 \%$} & \\
\hline
\end{tabular}

Berdasarkan Tabel 3 tampak bahwa rata-rata nilai 25 siswa yaitu 6,56 dengan rata-rata soal ke-1 3,04 dan soal ke-2 3,53. Jika dibandingkan rata-rata nilai 25 siswa dengan nilai KKM, dapat disimpulkan nilai 25 siswa tersebut dibawah nilai KKM, karena 6,56 lebih kecil dari 7, ini menunjukkan jika nilai tersebut berada di bawah nilai KKM. Rata-rata soal ke-1 3,04 dan soal ke-2 3,52, maka didapati rata-rata soal ke-2 lebih besar dari soal ke-1, ini menunjukkan nilai 25 siswa pada soal ke-2 lebih baik daripada soal ke-1. Selain dilihat dari rata-rata nilai 25 siswa pada soal ke-1 dan soal ke-2, dapat pula dilihat dari jumlah nilai soal ke-1 dan soal ke-2, jumlah soal ke-1 76 dan jumlah soal ke-2 88. Terlihat bahwa jumlah nilai soal ke-2 lebih besar daripada soal ke-1, karena nilai 88 lebih besar daripada nilai 76, yang berarti jumlah nilai soal ke-2 lebih besar daripada soal ke-1. Persentase kesalahan siswa ketika menjawab soal ke-1 sebanyak 39,2\% dan soal ke-2 sebanyak 29,6\%. Dapat disimpulkan dari 2 soal yang diberikan, soal nomor 1 lebih banyak persentase siswa yang melakukan kesalahan, karena 39,2\% lebih besar daripada 29,6\%. Rata-rata tingkat kesalahan siswa 
saat menjawab soal cerita SPLTV sebanyak $34,4 \%$ dan sisanya $65,6 \%$ siswa dapat menjawab dengan baik dan benar.

\section{SIMPULAN DAN SARAN}

Berdasarkan hasil jawaban siswa diperoleh rata-rata tingkat kesalahan siswa saat menjawab soal cerita SPLTV sebanyak 34,4\% dan sisanya 65,6\% siswa dapat menjawab dengan baik dan benar. Dari dua soal yang diberikan, soal nomor 1 lebih banyak persentase siswa yang melakukan kesalahan, karena 39,2\% lebih besar daripada $29,6 \%$. Ada bermacam-macam kesalahan siswa, berdasarkan analisis kesalahan menurut Newman diperoleh kesalahan membaca sebesar $0 \%$ yang artinya tidak terdapat satupun siswa yang salah dalam membaca soal karena semua siswa membaca soal dengan baik, kesalahan memahami sebesar 30,23\% disebabkan siswa tidak menulis diketahui dan ditanya, kesalahan transformasi sebesar 20,93\% disebabkan siswa belum mampu mentransformasikan soal yang diberikan menjadi bentuk matematis sehingga tidak bisa membuat model matematika, kesalahan keterampilan proses sebesar $24,42 \%$ disebabkan kurangnya ketelitian siswa dalam melakukan perhitungan yang mengakibatkan terjadinya kesalahan, dan kesalahan penulisan jawaban akhir sebesar 24,42\% disebabkan siswa kurang lengkap ketika membuat kesimpulan.

Saran yang dapat diberikan pada siswa yaitu harus lebih teliti dalam mengerjakan soal dan untuk guru sebaiknya lebih bervariasi dalam memberikan latihan soal mengenai masalah kontekstual agar siswa semakin terampil dalam menyelesaikan soal.

\section{DAFTAR PUSTAKA}

Agustini, D., \& Pujiastuti, H. (2020). Analisis Kesulitan Siswa Berdasarkan Kemampuan Pemahaman Matematis dalam Menyelesaikan Soal Cerita Pada Materi SPLDV. Media Pendidikan Matematika, 8(1), 18.

Aulia, Mirza. (2020). Mengembangkan Kemampuan Pemecahan Masalah Matematika Siswa Menggunakan Tugas Terstruktur Melalui Blog. SKRIPSI. Universitas Islam Negeri Ar-Raniry Darussalam.

Azwar, Saifudin. (2014). Pengantar Psikologi Intelegensi. Yogyakarta: Pustaka Pelajar.

Halim, F. A., \& Rasidah, N. I. (2019). Analisis Kesalahan Siswa dalam Menyelesaikan Soal Cerita Aritmatika Sosial Berdasarkan Prosedur Newman. GAUSS: Jurnal Pendidikan Matematika, 2(1), 35.

Hamsiah, H., Masjudin, M., \& Kurniawan, A. (2017). Analisis Kemampuan Penalaran Matematis Siswa SMPN 13 Mataram Pada Materi Bangun Ruang. Media Pendidikan Matematika, 5(2), 115.

Islamiyah, A. C., Prayitno, S., \& Amrullah, A. (2018). Analisis Kesalahan Siswa SMP pada Penyelesaian Masalah Sistem Persamaan Linear Dua Variabel. Jurnal Didaktik Matematika, 5(1), 66-76. 
Kurniawan, A., Juliangkary, E., \& Pratama, M. Y. (2019). Analisis Kesulitan Siswa Dalam Menyelesaikan Soal Fungsi. Media Pendidikan Matematika, 7(1), 72.

Rahmawati, D., \& Permata, L. D. (2018). Analisis Kesalahan Siswa Dalam Menyelesaikan Soal Cerita Program Linear Dengan Prosedur Newman. Jurnal Elektronik Pembelajaran Matematika, 5(2), 173-185.

Rusmania, N. (2015). Analisis Kesalahan Siswa SMP Kelas VIII Dalam Menyelesaikan Masalah Soal Cerita Matematika. Aksioma : Jurnal Pendidikan Matematika FKIP Univ. Muhammadiyah Metro, 4(2), 42-52.

Sholihah, M. (2018). Analisis Kesalahan Siswa Dalam Menyelesaikan Soal Cerita Matematika Kelas VII Mts Laboratorium UIN-SU T.p 2017/2018. Skripsi. UINSU Medan.

Wardhani, N., \& Firmansyah, D. (2019). Kesalahan Siswa Dalam Menyelesaikan Soal Cerita Matematika Menurut Prosedur Newman. Prosiding SESIOMADIKA, 2(4), 962-970. 